\title{
Predicting habitat use by the Argentine hake Merluccius hubbsi in a warmer world: inferences from the Middle Holocene
}

\author{
Maria Bas ${ }^{1,2}(1) \cdot$ Mónica Salemme $^{1,3} \cdot$ Eleanor Joan Green $^{4} \cdot$ Fernando Santiago $^{1} \cdot$ Camilla Speller $^{4,5}$. \\ Myrian Álvarez ${ }^{1}$ Ivan Briz i Godino ${ }^{1,6,7} \cdot$ Luis Cardona $^{2}$
}

Received: 17 May 2019 / Accepted: 6 May 2020

(c) Springer-Verlag GmbH Germany, part of Springer Nature 2020

\begin{abstract}
Fish skeletal remains recovered from two archaeological sites dated in the Middle Holocene of Tierra del Fuego (Argentina) were analysed to describe habitat use patterns by hake in the past and predict changes in a warmer world. Mitochondrial DNA was successfully extracted and amplified from 42 out of 45 first vertebra from ancient hake and phylogenetic analysis assigned all haplotypes to Argentine hake (Merluccius hubbsi). According to osteometry, the Argentine hake recovered from the archaeological site were likely adults ranging $37.2-58.1 \mathrm{~cm}$ in standard length. $\mathrm{C}$ and $\mathrm{N}$ stable isotope analysis showed that currently Argentine hake use foraging grounds deeper than those of Patagonian blenny and pink cusk-eel. Argentine hake, however, had a much broader isotopic niche during the Middle Holocene, when a large part of the population foraged much shallower than contemporary pink cusk-eel. The overall evidence suggests the presence of large numbers of Argentine hake onshore Tierra del Fuego during the Middle Holocene, which allowed exploitation by hunter-gatherer-fisher groups devoid of fishing technology. Interestingly, average SST off Tierra del Fuego during the Middle Holocene was higher than currently $\left(11^{\circ} \mathrm{C}\right.$ vs $\left.7{ }^{\circ} \mathrm{C}\right)$ and matched SST in the current southernmost onshore spawning aggregations, at latitude $47^{\circ} \mathrm{S}$. This indicates that increasing SST resulting from global warming will likely result into an increased abundance of adult Argentine hake onshore Tierra del Fuego, as during the Middle Holocene. Furthermore, stable isotope ratios from mollusc shells confirmed a much higher marine primary productivity during the Middle Holocene off Tierra del Fuego.
\end{abstract}

Keywords Hake $\cdot$ Osteometry $\cdot$ Stable isotopes $\cdot$ Tierra del Fuego $\cdot$ Zooarchaeology

\section{Introduction}

Global warming will modify fish distribution and abundance around the world, with tropical and subtropical species expanding poleward (Perry et al. 2005; Hiddink and Ter Hofstede 2008; Simpson et al. 2011), while those inhabit-

Communicated by Leon A. Barmuta.

Electronic supplementary material The online version of this article (https://doi.org/10.1007/s00442-020-04667-z) contains supplementary material, which is available to authorized users.

Maria Bas

mbaslpez@gmail.com

1 Centro Austral de Investigaciones Científicas (CADICCONICET), Ushuaia, Argentina

2 Department of Evolutionary Biology, Ecology and Environmental Science, Biodiversity Research Institute (IRBio), University of Barcelona, Barcelona, Spain

3 ICSE, Universidad Nacional de Tierra del Fuego, Ushuaia, Argentina ing colder regions are expected to change their depth range (Perry et al. 2005; Simpson et al. 2011). As a result, food web structure and dynamics are also expected to change

4 Department of Archaeology, BioArCh, University of York, York, UK

5 Department of Anthropology, University of British Columbia, Vancouver, BC, Canada

6 Department of Archaeology, University of York, York, UK

7 P. Rockefeller Visiting Scholar, DRCLAS at Harvard University, Cambridge, MA, USA 
(Hoegh-Guldberg and Bruno 2010; Simpson et al. 2011; Bas et al. 2019). Making precise predictions, however, about the consequences of global warming is challenging without a broad historical perspective (Swetnam et al. 1999; Jackson et al. 2001; Lotze et al. 2011; Friedlander et al. 2014).

The South-Western Atlantic Ocean is inhabited by two species of hake: the Argentine hake Merluccius hubbsi (Marini, 1933) and the Southern hake Merluccius australis (Hutton, 1872), which both support important commercial fisheries (Bezzi et al. 1995; Cousseau and Perrotta 1998; Bertolotti et al. 2001; Lloris et al. 2005). Commercial hake fishing began in Argentina in the 1960s and targeted mainly Argentine hake. Commercial fishing for Southern hake started in the 1990s, when shallow water stocks of Argentine hake were declining (Lloris et al. 2005). Both species are similar in morphology and biology, but the Southern hake is tightly linked to the cold Malvinas current, whereas the Argentine hake prevails on warmer waters over the continental shelf (Cousseau and Perrotta 1998; Lloris et al. 2005). Furthermore, the abundance of Argentine hake declines sharply south of $52^{\circ} \mathrm{S}$ and coastal summer spawning aggregations do not exist south of $47^{\circ} \mathrm{S}$ (Bezzi et al. 1995; Díaz de Astarloa et al. 2011), where annual average SST is $11^{\circ} \mathrm{C}$ (Rivas 2010). This suggests that in a warmer world, the Argentine hake could expand southward and replace the Southern hake off Tierra del Fuego.

The zooarchaeological record of ancient fishing societies offers an opportunity to explore changes through time on issues such as age-length relationships (Leach and Davidson 2001; Bolle et al. 2004), geographic distribution (Enghoff et al. 2007; Scartascini and Volpedo 2013; Bas et al. 2019) and trophic position (Zenteno et al. 2015; Braje et al. 2017; Szpak et al. 2018; Bas et al. 2019). The fish remains left by societies living in the warmer periods of the Holocene are particularly interesting since they offer a glimpse to a plausible future in the context of global warming (Bas et al. 2019).

The zooarchaeological record of Tierra del Fuego dates to the Early Holocene and hake (Merluccius sp.) abound in many archaeological sites since the Middle
Holocene (Torres 2009; Santiago 2013; Zangrando et al. 2016). According to a diversity of proxies, climate and SST during the Middle Holocene in the southernmost tip of South America were warmer than today (Bujalesky 2007; Shevenell et al. 2011; Caniupán et al. 2014). Currently, annual average SST off Tierra del Fuego is $7{ }^{\circ} \mathrm{C}$ (Rivas 2010), but was as high as $11-12{ }^{\circ} \mathrm{C}$ at $53^{\circ} \mathrm{S}$ during the Middle Holocene (Caniupán et al. 2014). Therefore, data on the biology of hake during the Middle Holocene can inform predictions of the future distributions of both species.

The recovery of 9000 skeletal elements from an unknown number of hake specimens from Río Chico 1 archaeological site (Santiago 2013), clearly demonstrates the existence of a huge coastal population of at least one hake species off north-eastern Tierra del Fuego during the Middle Holocene. That population has since disappeared and morphological analysis cannot distinguish the skeletal elements of Argentine and Southern hake other than hyomandibular and urohyal bones (Lloris et al. 2005). Therefore, the species of hake recovered from Río Chico 1 remains unknown and, nothing is known about the habitat where the Río Chico 1 hake were captured. The strong winds and currents in this region, coupled with the absence of sailing technology during the Middle Holocene suggest that aboriginal hunter-gatherer-fisher groups likely captured hake onshore, but hard evidence is missing. Stable isotope analysis can be informative about the habitat used by ancient hake, but detailed studies comparing the stable isotope ratios from sympatric Argentine and Southern hakes have not yet been published and the comparison of the existing data is hindered by very small sample sizes (Table 1).

Here, we analyse mitochondrial DNA of a subsample of hake skeletal elements recovered from Río Chico 1 to separate the species, reconstruct the body size of those specimens through osteometry, and track changes in trophic position and habitat over time by analysing stable isotope ratios of $\mathrm{C}$ and $\mathrm{N}$ of modern and ancient hake.
Table 1 Stable isotope ratios $\left(\delta^{13} \mathrm{C}\right.$ and $\left.\delta^{15} \mathrm{~N}\right)$ in the muscle and bone of modern specimens of marine fish species from the Patagonian Shelf (PS) and the Beagle Channel (BC)

\begin{tabular}{lrlllll}
\hline Species & $N$ & Location & Sample & $\delta^{13} \mathrm{C}(\% \circ)$ & $\delta^{15} \mathrm{~N}(\% \circ)$ & References \\
\hline Patagonian blenny & 20 & BC & Muscle & $-15.5 \pm 0.9$ & $16.4 \pm 0.4$ & Riccialdelli et al. (2017) \\
Patagonian blenny & 6 & PS & Muscle & $-14.9 \pm 0.3$ & $17.2 \pm 0.4$ & Ciancio et al. (2008) \\
Patagonian blenny & 5 & PS & Muscle & $-16.4 \pm 0.3$ & $18.5 \pm 0.8$ & Vales et al. (2017) \\
Argentine hake & 6 & PS & Muscle & $-18.2 \pm 0.9$ & $17.0 \pm 0.1$ & Ciancio et al. (2008) \\
Argentine hake & 5 & PS & Muscle & $-17.2 \pm 0.8$ & $16.2 \pm 0.9$ & Botto et al. (2019) \\
Southern hake & 3 & PS & Muscle & $-17.4 \pm 1.0$ & $18.6 \pm 0.6$ & Ciancio et al. (2008) \\
Pink cusk-eel & 5 & PS & Muscle & $-17.5 \pm 0.2$ & $17.7 \pm 0.2$ & Ciancio et al. (2008) \\
Patagonian blenny & 15 & PS & Bone & $-9.7 \pm 1.4$ & $16.0 \pm 0.7$ & Bas and Cardona (2018) \\
Argentine hake & 3 & PS & Bone & $-14.6 \pm 1.0$ & $16.8 \pm 1.3$ & Zangrando et al. (2016) \\
Southern hake & 15 & PS & Bone & $-13.9 \pm 0.8$ & $16.8 \pm 0.9$ & Zangrando et al. (2016) \\
\hline
\end{tabular}




\section{Materials and methods}

\section{Study area and sample collection}

The study area is located at the Atlantic Coast of Isla Grande de Tierra del Fuego, Argentina. The samples were collected from two distinct archaeological sites from the Middle Holocene (Online Resource 1). Two radiocarbon dates are available for the shell midden called Río Chico 1:5828 \pm 46 $\mathrm{BP}$ and $5856 \pm 44 \mathrm{BP}$, corresponding to $6558 \mathrm{cal} \mathrm{BP}$ and 6260 cal BP (lab codes AA75285 and AA65165, respectively; Santiago 2013). They are comparable to those for the nearby archaeological site known as La Arcillosa 2: $5508 \pm 48 \mathrm{BP}$ and $5068 \pm 66 \mathrm{BP}$, corresponding to $5868 \mathrm{cal}$ BP and 5776 cal BP (lab codes AA60934 and AA102166; Salemme et al. 2007, 2014).

The faunal assemblage at the shell midden Río Chico 1 is largely dominated by fish elements, followed by bird and mammal bones (Santiago 2013). Conversely, La Arcillosa 2 is a shell midden dominated by mammal remains, followed by bird and fish bones (Salemme et al. 2014). Limpets [Nacella magellanica (Gmelin, 1791)] and mussels [Mytilus chilensis (Hupé, 1854)] also occur at both sites. The latter dominates the malacological samples by more than $90 \%$ in both archaeological sites (Santiago et al. 2014).

Bones from ancient hake of unknown species identity, pink cusk-eel [Genypterus blacodes (Forster, 1901)] and Patagonian blenny [Eleginops maclovinus (Cuvier, 1830)], as well as shells of limpet and mussel, were recovered from Río Chico 1 and La Arcillosa 2 (Table 2); all these samples were stored dry until further analysis. To avoid pseudoreplication, only the first vertebra was selected for hake, and bones from the neurocranium with the same laterality were used for the other fish species. Modern adult Argentine hake, Southern hake, pink cusk-eel and Patagonian blenny specimens were captured at the adjoining Atlantic Ocean and then bones were collected for stable isotope analysis (Online Resource 1). Shells from modern limpets and mussels were collected from the open-water beach, Punta María, on the adjoining Atlantic Ocean (Online Resource 1). All the specimens were sampled between 2016 and 2017 and stored at $-20^{\circ} \mathrm{C}$ until further analysis.

Pink cusk-eel and Patagonian blenny provide benchmarks to interpret the stable isotope ratios of $\mathrm{C}$ in ancient hake. Previous research has demonstrated no significant differences in stable isotope ratios of $\mathrm{C}$ and $\mathrm{N}$ across skeletal elements in fish with acellular bone (Bas and Cardona 2018), so the stable isotope ratio of hake, pink cusk-eel and Patagonian blenny can be compared directly although different skeletal elements have been analysed. The trophic positions of the pink cusk-eel and the Patagonian blenny are similar to those of the two hake species (Table 1), but the two former species differ in habitat selection. The pink cusk-eel is broadly distributed across the continental shelf and the upper slope (Villarino 1998), although is rare in very shallow coastal habitats (Pequeño et al. 1995; Cousseau and Perrotta 1998). Conversely, the Patagonian blenny is a coastal species highly associated with shallow areas influenced by freshwater runoff (Pequeño et al. 1995; Cousseau and Perrotta 1998; Quiñones and Montes 2001; Licandeo et al. 2006; Riccialdelli et al. 2017). As a result, the $\delta^{13} \mathrm{C}$ value of the pink cusk-eel is much lower than that of sympatric Patagonian blenny, and similar to that of both hake species (Table 1). Thus, if ancient hake recovered from Río Chico 1 inhabited more onshore areas than they do currently, their $\delta^{13} \mathrm{C}$ values were expected to be significantly higher than those of contemporary pink cusk-eel and modern hake and closer to those of contemporary Patagonian blenny.

Table 2 Stable isotope ratios $\left(\delta^{13} \mathrm{C}\right.$ and $\left.\delta^{15} \mathrm{~N}\right)$ of ancient and modern fish from the Atlantic coast of Tierra del Fuego

\begin{tabular}{|c|c|c|c|c|c|c|c|c|c|c|c|}
\hline Species & $N$ & Location & Sample & $\delta^{13} \mathrm{C}(\% \circ)$ & $\delta^{13} \mathrm{C}_{\text {corr }}(\% o)$ & $\delta^{15} \mathrm{~N}(\% o)$ & $\delta^{15} \mathrm{~N}_{\text {corr }}(\% o)$ & $\mathrm{TP}$ & $\mathrm{SEA}_{\mathrm{C}}$ & $\mathrm{SEA}_{\mathrm{B}}$ & TA \\
\hline \multicolumn{12}{|l|}{ MODERN } \\
\hline Argentine hake & 20 & $\mathrm{AC}$ & 1st Vert & $-14.4 \pm 0.6$ & - & $15.9 \pm 0.7$ & - & $3.3 \pm 0.2$ & 1.3 & $1.2[0.7-1.9]$ & 3.4 \\
\hline Southern hake & 30 & $\mathrm{AC}$ & 1st Vert & $-14.9 \pm 0.9$ & - & $15.0 \pm 1.5$ & - & $3.0 \pm 0.5$ & - & - & - \\
\hline Pink cusk-eel & 5 & $\mathrm{AC}$ & Vert & $-13.4 \pm 0.6$ & - & $16.5 \pm 0.3$ & - & - & - & - & - \\
\hline Patagonian blenny & 15 & $\mathrm{AC}$ & Vert & $-9.5 \pm 1.4$ & - & $15.2 \pm 0.6$ & - & - & - & - & - \\
\hline \multicolumn{12}{|l|}{ ANCIENT } \\
\hline Argentine hake & 42 & $\mathrm{RC} 1$ & 1st Vert & $-15.0 \pm 1.1$ & $-12.3 \pm 1.1$ & $16.6 \pm 0.7$ & $15.7 \pm 0.7$ & $3.2 \pm 0.3$ & 2.5 & $2.5[1.8-3.3]$ & 10.0 \\
\hline Pink cusk-eel & 5 & $\mathrm{RC} 1$ & Basiocc & $-16.9 \pm 0.5$ & $-14.2 \pm 0.5$ & $16.4 \pm 0.6$ & $15.4 \pm 0.6$ & - & - & - & - \\
\hline Patagonian blenny & 2 & LA2 & Premax & $-15.4 \pm 3.0$ & $-10.7 \pm 3.0$ & $12.9 \pm 1.5$ & $10.3 \pm 1.5$ & - & - & - & - \\
\hline
\end{tabular}

Trophic position (TP), SEA, $\mathrm{SEA}_{\mathrm{B}}$ and TA of ancient and modern ones are also reported for fishes. All modern fishes were collected in the Atlantic coast of Tierra del Fuego (AC; Online Resource 1). Ancient samples were recovered from Río Chico 1 (RC1) and La Arcillosa 2 (LA2) archaeological sites (Online Resource 1). Vert.: Vertebra bone; Basiocc.: Bassiocipital bone; Premax.: Premaxilla bone. $\delta^{13} \mathrm{C}, \delta^{13} \mathrm{C}_{\text {corr }}, \delta^{15} \mathrm{~N}$, $\delta^{15} \mathrm{~N}_{\text {corr, }}$ values are reported by mean $\pm \mathrm{SD}$. Correction Factor was calculated by the difference between mean isotope values of molluscs of modern and ancient samples, respectively. Consult Online Resource 4 for the raw data of stable isotope ratios 


\section{Hake identification and taxonomy}

The species identity of the ancient hake specimens was identified through ancient mitochondrial DNA (mtDNA) analysis. DNA was extracted in the Ancient DNA Laboratory at the University of York, which follows strict protocols for contamination control and detection, including positive pressure, the use of protective clothing, UV sources for workspace decontamination, and laminar flow hoods for extraction and PCR-set-up. The 45 hake bones were subsampled prior to isotopic analysis, providing between 2.7 and $35 \mathrm{mg}$ of bone for analysis (see Online Resource 2). The bone samples were crushed using a micropestle, and DNA was extracted using a silica spin column protocol (Yang et al. 1998) modified as reported in Yang et al. (2008); DNA was eluted in a $50 \mu \mathrm{L}$ volume. Blank extractions and negative controls were included within all extraction batches and PCR amplifications.

Primers were designed to target a $295 \mathrm{bp}$ fragment of the mtDNA cytochrome b (cytb) gene, which can distinguish species within the genus Merluccius (Campo et al. 2007) bracketing positions 14,556-14,851 of the M. merluccius mitochondrial genome, Genbank accession NC015120; Forward primer-F14556 5'-ACCGCA AACGTCGAAATAGC-3' and reviser primer R14851 5'-GGTACGGCAGACATTAAGTTTGTG-3'. PCR reactions were prepared and amplified following Speller et al. (2012) using an annealing temperature of $55^{\circ} \mathrm{C}$, and successfully amplified PCR products were sequenced using forward and/or reverse primers at Eurofins Genomics, Ebersberg, Germany. The obtained sequences were visually edited using the ChromasPro software (www.techn elysium.com.au), truncated to remove primer sequences, resulting in a final sequence length of $232 \mathrm{bp}$ [positions 14,596-14827]; haplotypes were assigned using this longer fragment. Forty-two sequences were uploaded to the Genetic Sequence Database at the National Center for Biotechnical Information (NCBI) (GenBank ID: MK882658-MK882699).

Edited sequences were initially compared with published references through the GenBank BLAST application (https ://www.ncbi.nlm.nih.gov/BLAST/) to ensure they matched with Merluccius species. Multiple alignments of the ancient sequences with 98 published Merluccius sequences were conducted using ClustalW (Thompson et al. 1994), through BioEdit (Hall 2001). Species identifications were assigned through phylogenetic analysis of a $175 \mathrm{bp}$ fragment comparable to available reference sequences. The ModelTest (Version 2.3) software (Posada and Crandall 1998) was employed to determine the best-fit model (GTR + G, selected by AIC), implemented in MrBayes 3.2.5 (Ronquist and Huelsenbeck 2003). Ten million generations of analyses were performed to produce the phylogeny and clade credibility scores, with a burnin of one million generations. Phylogenetic trees were created using FigTree 1.4.0 (Rambaut 2007).

\section{Size distribution analysis}

The caudal fin of most of the modern specimens of Argentine and Southern hake sampled for this study was damaged, so fish size was measured as standard length (SL). The overall sample size was larger and the size interval was broader for Southern hake $(N=30 ; \mathrm{SL}=43.3-69.6 \mathrm{~cm})$ than for the Argentine hake $(N=20 ; \mathrm{SL}=55.0-67.0 \mathrm{~cm})$. Fish were slightly boiled, flesh removed, the skeleton was disarticulated and stored dry. The morphometric analysis focused on vertebrae because they are the most common skeletal element recovered from Río Chico 1 . The axial skeleton of hake can be differentiated into three different types of vertebrae (Online Resource 3), but only the first thoracic vertebra can be individually recognized. Accordingly, the analysis focused on the first vertebra and three measurements were considered: the dorso-ventral height of the centrum (M1), the medium-horizontal width of the centrum (M2) and craniocaudal length of the centrum (M3) (Online Resource 3; Morales and Rosenlund 1979).

The morphometric analysis was conducted on the two species, but only the equation relating the dorso-ventral height of the centrum and the SL of Southern hake was used to assess the size of the ancient hake (see below). This is because the dorso-ventral height of most of the centra recovered from Río Chico 1 was outside the range of the centra measured from modern Argentine hake, thus indicating that the specimens recovered from Río Chico 1 were much smaller than those in our sample of Argentine hake. Conversely, the range of the centra recovered from Río Chico 1 overlapped broadly with that of the centra from the sample of modern Southern hake. Furthermore, the equations derived for both hake species yield the same results for the overlapping range of SL values $(55.0-67.0 \mathrm{~cm})$.

\section{Stable isotope analysis}

As previously reported, all modern samples were stored in a freezer at $-20{ }^{\circ} \mathrm{C}$ until analysis. Soft tissues were removed from limpets and mussels and the shells were rinsed with water, dried at room temperature and lightly scraped with sand paper to remove epibionts. Fishes were thawed at room temperature, boiled between 5 and $10 \mathrm{~min}$ and dissected to remove the selected bones. Shells and bones were latter dried in a stove at $60{ }^{\circ} \mathrm{C}$ for $24 \mathrm{~h}$. Once dry, each sample was ground to fine powder and divided into two subsamples. This is because calcium carbonate and lipids have to be removed to obtain unbiased $\delta^{13} \mathrm{C}$ values (Newsome et al. 2006; Guiry et al. 2016; Bas and Cardona 2018), but demineralization consistently increases 
the $\delta^{15} \mathrm{~N}$ values of the organic matrix (Bas and Cardona 2018). One subsample ("bulk" hereafter) was ground to fine powder with mortar and pestle and approximately $0.7 \mathrm{mg}$ of bone powder were weighed into $3.3 \times 5 \mathrm{~mm}$ tin cups, $7 \mathrm{mg}$ of modern shell powder were weighed into $5 \times 8 \mathrm{~mm}$ tin cups and $14 \mathrm{mg}$ of ancient shell powder were weighed into $5 \times 8 \mathrm{~mm}$ tin cups. The other bone subsample ("dml" hereafter) was ground to fine powder with mortar and pestle, dried again for $24 \mathrm{~h}$ at $60{ }^{\circ} \mathrm{C}$ and rinsed with a $2: 1$ chloroform:methanol solution to remove lipids (Folch et al. 1957). The chloroform:methanol solution was changed overnight until it was transparent. Bone $\mathrm{dml}_{\mathrm{dm}}$ subsamples were dried again for $24 \mathrm{~h}$ at $60^{\circ} \mathrm{C}$ and demineralized with $0.5 \mathrm{~N}$ hydrochloric acid $(\mathrm{HCl})$ until no more $\mathrm{CO}_{2}$ bubbles were released (Newsome et al. 2006; Bas and Cardona 2018). Shell $\mathrm{dml}_{\mathrm{dm}}$ subsamples were first demineralised by soaking in $1 \mathrm{~N} \mathrm{HCl}$ until no more $\mathrm{CO}_{2}$ was released (Saporiti et al. 2014a). After demineralization, shell $\mathrm{dml}_{\mathrm{ml}}$ subsamples were rinsed with distilled water for $24 \mathrm{~h}$, dried again for $24 \mathrm{~h}$ at $60{ }^{\circ} \mathrm{C}$ and mixed with a 2:1 chloroform:methanol solution to remove lipids. The chloroform:methanol solution was changed overnight until it was transparent. Then, samples were dried again for $24 \mathrm{~h}$ at $60{ }^{\circ} \mathrm{C}$ and $0.5 \mathrm{mg}$ were weighed into $3.3 \times 5 \mathrm{~mm}$ tin cups.

All tin cups were combusted at $900{ }^{\circ} \mathrm{C}$ and analysed in a continuous flow isotope ratio mass spectrometer (Flash 1112 IRMS Delta C Series EA, Thermo Finnigan; www. thermofisher.com) at Centres Científics i Tecnològics de la Universitat de Barcelona (www.ccit.ub.edu) in Barcelona, Spain. Gases from the combustion of bulk shell samples passed through a $\mathrm{CO}_{2}$ absorbent column for elemental analysis, containing $\mathrm{CaO} / \mathrm{NaOH}$. This was to avoid spectrometer saturation with $\mathrm{CO}_{2}$, because $\mathrm{CaCO}_{3}$ constitutes over $90 \%$ of the shells samples and large amount of shell had to be combusted to obtain enough $\mathrm{N}$ to measure $\delta^{15} \mathrm{~N}$ values.

Abundance of stable isotopes is expressed using the $\delta$ notation, where the relative variations of stable isotope ratios is expressed as per mil (\%o) deviations from predefined reference scales: Vienna Pee Dee Belemnite (VPDB) calcium carbonate for $\delta^{13} \mathrm{C}$ and atmospheric nitrogen (AIR) for $\delta^{15} \mathrm{~N}$. Due to limited supplies, however, isotopic reference materials, which included known isotopic compositions relative to international measurement standards, were analysed instead. All these isotopic reference materials were employed to recalibrate the system once every 12 samples and were analysed to compensate for any measurement drift over time. The raw data were recalculated taking into account a linear regression previously calculated for isotopic reference materials (Skrzypek 2013). Following Bas and Cardona (2018), only $\delta^{13} \mathrm{C}_{\mathrm{dml}}$ and $\delta^{15} \mathrm{~N}_{\text {bulk }}$ values were used for latter analysis. Furthermore, the carbon to nitrogen $(\mathrm{C}: \mathrm{N})$ atomic ratio of each dml subsample was used to assess the efficiency of lipid extraction (DeNiro 1985). The stable isotope ratios and the C:N ratios of all the samples are available as Online Resource 4.

\section{Data analysis}

First, linear regression was used the identify which of the three dimensions of vertebra centrum (M1, M2, and M3) best predicted the SL of modern hake specimens and that parameter was used to reconstruct the size of the ancient hake.

Secondly, the stable isotope ratios of modern and ancient organisms cannot be compared directly, because the isotopic baseline may vary temporally (Casey and Post 2011). Nonetheless, the proteins that make up the organic matrix of mollusc shells are preserved and unaffected by diagenetic changes (Misarti et al. 2017), hence offering material suitable to reconstruct the changes in the isotopic baseline (Casey and Post 2011; Drago et al. 2017; Misarti et al. 2017; Vales et al. 2017). Accordingly, values of $\delta^{13} \mathrm{C}$ and $\delta^{15} \mathrm{~N}$ of ancient limpets and mussels from Río Chico 1 and La Arcillosa 2 and modern conspecifics were compared independently using General Linear Models (GLM) as run in IBM SPSS Statistics (Version 23.0.0.2 for Mac) with two fixed factors (period and species) followed by a Tukey's (HSD) post-hoc test to assess the temporal variation of the $\delta^{13} \mathrm{C}$ and $\delta^{15} \mathrm{~N}$ values in shells. This approach was not possible for fish, because all the ancient Argentine hake and pink cusk-eel samples come from Río Chico 1 and all the ancient samples of the Patagonian blenny come from La Arcillosa 2.

Third, Pearson correlation coefficients were computed to assess linear relationships between $\delta^{13} \mathrm{C}, \delta^{15} \mathrm{~N}$ and trophic position (TP) values and fish size for both hake species and for both periods. According to correlation results, GLM was run with one fixed factor (species or period) and SL as a covariate to compare the $\delta^{13} \mathrm{C}, \delta^{15} \mathrm{~N}$ and TP average values of each species in the two periods considered, after correcting for any baseline shift following mollusc stable isotope ratios. In cases for which correlations were not significant, a Student's $t$-test was performed instead of GLM with the SL as a covariate. Normality and homoscedasticity assumptions were checked by means of Lilliefors test and Levene test, respectively.

The trophic position of each species $\left(T P_{p}\right)$ was calculated as:

$\mathrm{TP}_{p}=\left[\left(\delta^{15} \mathrm{~N}_{p}-\delta^{15} \mathrm{~N}_{m}\right) / 3\right]+2$

where $\delta^{15} \mathrm{~N}_{p}$ is the $\delta^{15} \mathrm{~N}$ average values of each species; $\delta^{15} \mathrm{~N}_{m}$ is the $\delta^{15} \mathrm{~N}$ average value of molluscs; three corresponds to Trophic Discrimination Factor (TDF); and mussels and limpets were considered herbivores at $\mathrm{TP}=2$ (Caut et al. 2009). Baseline corrections are necessary to compare 
the stable isotope ratios of consumers from different systems, as differences in the stable isotope ratios of primary producers propagate to consumers. On the contrary, no correction is needed to compare the TP of the consumers from different systems, because TP is calculated independently for each food web and hence accounts for any difference in the isotopic baseline.

Fourth, SIBER (Stable Isotope Bayesian Ellipses in R; Jackson et al. 2011), was used to calculate standard ellipses to compare the size of the isotopic niche of the Argentine hake population for each period (Layman et al. 2007). The area of the convex hull and standard ellipse are independent from any difference in the isotopic baseline. For Argentine hake, both in the ancient and the modern specimens, the total area of the convex hull (TA) and two estimates of the ellipse area $\left(\mathrm{SEA}_{\mathrm{C}}\right.$ and $\mathrm{SEA}_{\mathrm{B}}$ ) were calculated. SEA $\mathrm{C}$ is the area of the standard ellipse corrected for small sample size but has no information about the associated error (calculated with p.interval $=0.95$ ). $\mathrm{SEA}_{\mathrm{B}}$ is the Bayesian estimate of the standard ellipse area and is reported as median values and $95 \%$ credible intervals, as calculated by SIBER. All codes for SIBER analyses are contained in the package SIBER (Jackson et al. 2011).

\section{Results}

\section{Hake identification and taxonomy}

Mitochondrial DNA was successfully extracted and amplified from 42 of the 45 samples, identifying six cytb haplotypes (see Online Resource 2); phylogenetic analysis assigned all six haplotypes to $M$. hubbsi (Fig. 1). The majority $(N=30)$ of the samples carried the same cytb haplotype (Mhub2). Seven samples were assigned to haplotype Mhub1, two samples were assigned to Mhub5 and three samples carried unique cytb haplotypes (Mhub3, Mhub4, and Mhub6). No amplifications were observed within the blank extractions and negative controls; all unique haplotypes underwent repeat amplification and sequencing to ensure that polymorphisms were not the result of DNA damage or sequencing error.

\section{Size distribution analysis}

The dorso-ventral height of the centrum (M1) was the best predictor of fish body size $\left(F_{1,28}=422.13 ; P<0.001 ; r^{2}=0.938\right)$ and hence was used to calculate the size of the ancient hake recovered from Río Chico 1 following this equation:

$\mathrm{SL}=(2.13+\mathrm{M} 1) / 0.016$

The recovered hake ranged from 37.2 to $58.1 \mathrm{~cm} \mathrm{SL}$.

\section{Stable isotope analysis}

Collagen yield from fish bones ranged $12.3-22.5 \%$ and the C:N ratio ranged 2.3-3.7 (Online resource 4).

Body size (SL) was weakly correlated with $\delta^{15} \mathrm{~N}$ and TP values in modern Southern hake $(r=0.404, P=0.013$; $r=0.404, P=0.013$; respectively), but was uncorrelated with $\delta^{13} \mathrm{C}$ values $(r=0.197, P=0.149)$. On the other hand, body size (SL) of modern Argentine hake was uncorrelated with $\delta^{13} \mathrm{C}, \delta^{15} \mathrm{~N}$ or TP $(r=0.011, P=0.483 ; r=0.264, P=0.145$; $r=0.263, P=0.146$; respectively), but there was a weak, positive correlation between $\delta^{13} \mathrm{C}$ values and SL in ancient Argentine hake $(\mathrm{r}=0.417, P=0.003)$. There was no correlation between $\delta^{15} \mathrm{~N}$ and TP values and SL in ancient Argentine hake $(r=0.197, P=0.109 ; r=0.195, P=0.111$; respectively).

The stable isotope ratios of $\mathrm{C}$ and $\mathrm{N}$ from mollusc shells of each period were normally distributed and were homoscedastic. Statistically significant differences existed between the $\delta^{13} \mathrm{C}$ values of limpets and mussels, as well as throughout time, but there was a statistically significant period $\times$ species interaction term (Table 3). Tukey's post-hoc tests revealed that a significant interaction term emerged because the $\delta^{13} \mathrm{C}$ values of modern limpets were higher than those of conspecifics from both ancient sites and this was also true for the $\delta^{13} \mathrm{C}$ values of modern mussels and their conspecifics from La Arcillosa 2, but modern mussels did not differ from the ancient mussels from Río Chico 1 (Fig. 2). Conversely, differences in the $\delta^{15} \mathrm{~N}$ values of contemporary mussels and limpets were not statistically significant, but they changed over time, although there was a significant period x species interaction term (Table 3). Tukey's post-hoc tests revealed that the significant interaction term resulted because the $\delta^{15} \mathrm{~N}$ values of modern mussels were lower than those of conspecifics from both ancient sites and the same was true for the $\delta^{15} \mathrm{~N}$ values of modern limpets compared to ancient conspecifics from La Arcillosa 2 but not compared to ancient limpets from Río Chico 1 (Fig. 2). Nevertheless, it should be noted that mean $\delta^{13} \mathrm{C}$ and $\delta^{15} \mathrm{~N}$ values of both limpets and mussels from Río Chico 1 were always in between those of La Arcillosa 2 and Punta María (Fig. 2). This suggests that a baseline shift certainly existed between ancient (Río Chico 1 and La Arcillosa 2) and modern (Punta María) $\delta^{13} \mathrm{C}$ and $\delta^{15} \mathrm{~N}$ values and that the inconsistent differences between Río Chico 1 and Punta María likely result from a small sample size and a low statistical power. Because of this, we calculated correction factors to account for baseline shifts and allow the comparison of ancient and modern fish stable isotope ratios. To do so, we averaged the stable isotope ratios of ancient limpets and mussels from each site (Río Chico $1 \delta^{13} \mathrm{C}=2.64 \%$ o and $\delta^{15} \mathrm{~N}=0.93 \%$; La Arcillosa 2: $\delta^{13} \mathrm{C}=4.65 \% \circ$ and $\delta^{15} \mathrm{~N}=2.61 \%$ ) and calculated the offset with the average stable isotope ratios from modern limpets 


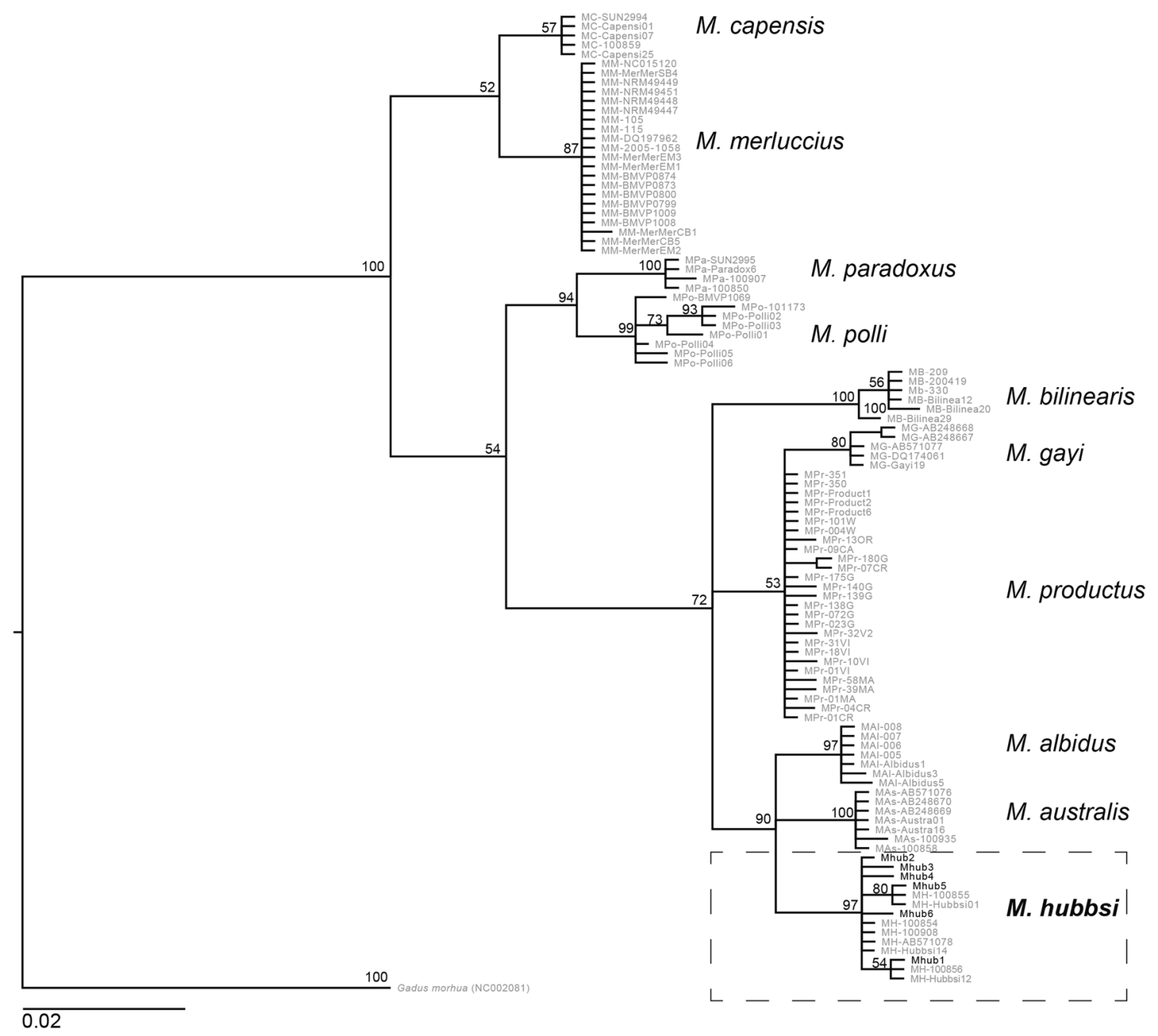

Fig. 1 Phylogenetic tree displaying the relationships between obtained ancient haplotypes (denoted by bold type) and published Merluccius cytochrome b sequences from GenBank. The Bayesian (Monte Carlo-Markov chain) consensus tree was composed using MrBayes 3.2.5 with Atlantic cod (Gadus morhua NC002081) as

and mussels. Later, we subtracted the offset from the $\delta^{13} \mathrm{C}$ and $\delta^{15} \mathrm{~N}$ values of ancient fish samples, to correct for the baseline shift and allow the comparison with modern values. Baseline corrected values are shown in Table 2 as $\delta^{13} \mathrm{C}_{\text {corr }}$ and $\delta^{15} \mathrm{~N}_{\text {corr }}$. The $\delta^{13} \mathrm{C}$ and $\delta^{15} \mathrm{~N}$ values from Argentine hake and pink cusk-eel that came from Río Chico 1 were corrected taking into account the correction factor calculated for this archaeological site (see above), and the same for he $\delta^{13} \mathrm{C}$ and $\delta^{15} \mathrm{~N}$ values from Patagonian blenny that came from La Arcillosa 2.

Currently, Argentine and Southern hake differed significantly in $\delta^{15} \mathrm{~N}$, TP (Table 4$)$ and $\delta^{13} \mathrm{C}$ values $\left(t_{48}=-2.317\right.$, $P=0.025)$. On the other hand, the $\delta^{13} \mathrm{C}_{\text {corr }}$ values of ancient Argentine hake were significantly higher than those of modern ones (Table 4). Nonetheless, there were no significant the outgroup. Model parameters $(\mathrm{GTR}+\mathrm{G})$ were identified through MrModelTest 2.3 and consensus trees were generated from two runs of MrBayes using 10 million generations each. Posterior probabilities of the major nodes are listed for each of the branches

differences between modern and ancient Argentine hake for $\delta^{15} \mathrm{~N}_{\text {corr }}$ or TP $\left(t_{59}=0.887, P=0.379 ; t_{59}=0.077, P=0.939\right.$, respectively). This result suggests that adult Argentine hake have not changed their trophic position over time, but have moved offshore. Related to these results, the credible intervals of the $\mathrm{SEA}_{\mathrm{B}}$ from ancient and modern Argentine hake overlap (Table 2), and something similar occurred with the SEA $_{C}$, which overlaps but in different ways (Fig. 3). Overlapping area of the modern specimens correspond to 58.6\%, whereas the ancient specimens correspond to $29.7 \%$. In general, values of $\mathrm{SEA}_{\mathrm{C}}, \mathrm{SEA}_{\mathrm{B}}$ and TA are higher in ancient Argentine hake than in modern ones suggesting a higher diversity of individual foraging strategies in the past.

The topologies of ancient and modern fish in the $\delta^{13} \mathrm{C}-\delta^{15} \mathrm{~N}$ isospace revealed two major differences at 
Table 3 Summary statistics of GLMs to assess the effect of sampling period and species identity (fixed factors) on the temporal variation of the $\delta^{13} \mathrm{C}$ and $\delta^{15} \mathrm{~N}$ values in shells from ancient (Río Chico 1 and La Arcillosa 2; Online Resource 1) and modern (Punta María; Online Resource 1) samples

\begin{tabular}{lrrrrr}
\hline & \multicolumn{1}{l}{ SS } & $d f$ & MS & \multicolumn{1}{l}{$F$} & \multicolumn{1}{l}{$P$} \\
\hline$\delta^{13} \mathrm{C}(\%)$ & & & & & \\
$\quad$ Period & 108.945 & 2 & 54.473 & 32.190 & $<0.01^{*}$ \\
$\quad$ Species & 22.171 & 1 & 22.171 & 13.102 & $<0.01^{*}$ \\
$\quad$ Period $\times$ species interac- & 29.883 & 2 & 14.942 & 8.830 & $<0.01^{*}$ \\
$\quad$ tion & & & & & \\
$\quad$ Residuals & 40.613 & 24 & 1.692 & & \\
$\delta^{15} \mathrm{~N}(\% o)$ & & & & & \\
$\quad$ Period & 35.068 & 2 & 17.534 & 37.442 & $<0.01^{*}$ \\
$\quad$ Species & 0.420 & 1 & 0.420 & 0.897 & 0.353 \\
$\quad$ Period $\times$ species interac- & 7.381 & 2 & 3.691 & 7.881 & $<0.01^{*}$ \\
$\quad$ tion & & & & & \\
$\quad$ Residuals & 11.239 & 24 & 0.468 & & \\
\hline
\end{tabular}

*Denote statistically significant differences $(P<0.05)$ between ancient and modern shell samples

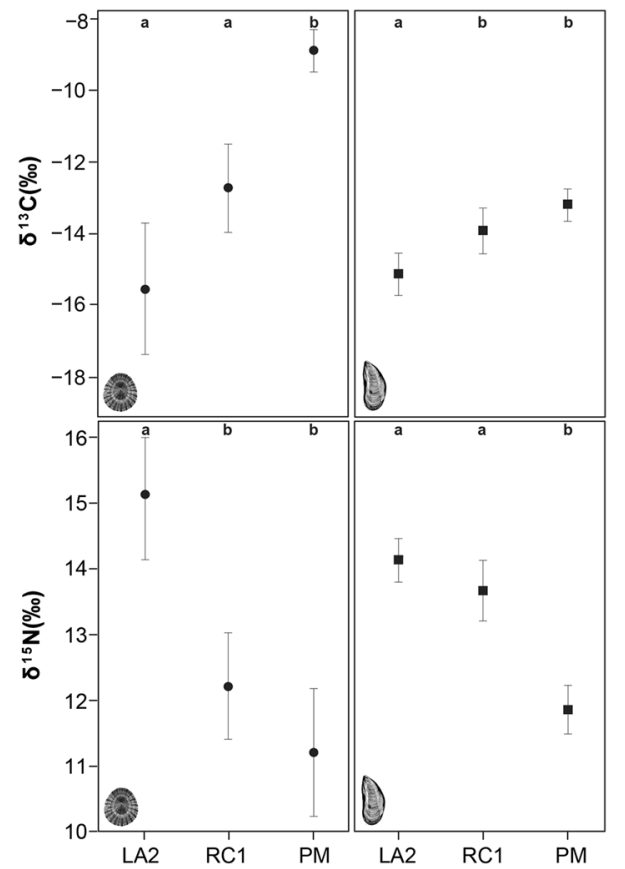

Fig. 2 Stable isotope ratios (mean \pm standard deviation) of ancient and modern mollusc shells from the Atlantic coast of Tierra del Fuego. Modern mollusc shells were collected in Punta María (PM; Online Resource 1). Ancient samples were recovered from Río Chico 1 (RC1) and La Arcillosa 2 (LA2) archaeological sites (Online Resource 1). Homogenous subsets were identified according to the results of post-hoc Tuckey's tests. Letters denote statistically significant differences between $\delta^{13} \mathrm{C}$ and $\delta^{15} \mathrm{~N}$ values from different periods and species, respectively. Sample size is $N=5$ for each species and location. Consult Online Resource 4 for the raw data of stable isotope ratios
Table 4 Summary statistics of GLMs to assess the effect of species identity (fixed factor) and body size (covariate) on $\delta^{15} \mathrm{~N}$ and TP of modern Argentine and Southern hake and the effect of period (fixed factor) and body size (covariate) on the $\delta^{13} \mathrm{C}$ values of modern and ancient Argentine hake

\begin{tabular}{lrrrrr}
\hline \multicolumn{1}{c}{ SS } & $d f$ & \multicolumn{1}{c}{ MS } & \multicolumn{1}{l}{$F$} & \multicolumn{1}{l}{$P$} \\
\hline$\delta^{15} \mathrm{~N}(\% \circ)$ & & & & & \\
$\quad$ Size & 11.299 & 1 & 11.299 & 7.671 & $<0.01^{*}$ \\
$\quad$ Species & 3.672 & 1 & 3.672 & 2.493 & 0.121 \\
$\quad$ Residuals & 66.286 & 45 & 1.473 & & \\
Trophic position & & & & & \\
$\quad$ Size & 1.256 & 1 & 1.256 & 7.666 & $<0.01^{*}$ \\
$\quad$ Species & 0.410 & 1 & 0.410 & 2.504 & 0.121 \\
$\quad$ Residuals & 7.370 & 45 & 0.164 & & \\
$\delta^{13} \mathrm{C}(\%)$ & & & & & \\
$\quad$ Size & 7.344 & 1 & 7.344 & 7.811 & $<0.01^{*}$ \\
Period & 36.836 & 1 & 36.836 & 39.178 & $<0.01^{*}$ \\
Residuals & 54.533 & 58 & 0.940 & & \\
\hline
\end{tabular}

*Denote statistically significant effects $(P<0.05)$

species level (Fig. 4). The first and most relevant was the dissimilar position of ancient Argentine hake compared to the pink cusk-eel and the Patagonian blenny, suggesting a more coastal habitat for Argentine hake during the Middle Holocene. Secondly, Patagonian blenny had lower $\delta^{15} \mathrm{~N}$ values in the past, thus revealing differences in trophic position between ancient and modern samples.

\section{Discussion}

The results of this study demonstrate that ancient Argentine hake inhabiting the Atlantic coast of Tierra del Fuego during the Middle Holocene had a broader isotopic niche and foraged on average in more coastal habitats than currently. This suggests that ancient Argentine hake might have gathered at least seasonally so close to the shore to be captured by ancient hunter-gatherer-fishers devoid of sailing technology. Currently, dense coastal aggregations of hake occur only north of $47^{\circ} \mathrm{S}$ during summer spawning (Bezzi et al. 1995; Díaz de Astarloa et al. 2011) and annual average SST is at least $11^{\circ} \mathrm{C}$ in those areas (Rivas 2010). On the other hand, SST off north-eastern Tierra del Fuego is $7{ }^{\circ} \mathrm{C}$ (Rivas 2010) and spawning aggregations do not exist (Bezzi et al. 1995; Díaz de Astarloa et al. 2011). If environmental conditions in a warmer world would match those prevailing in the Middle Holocene, the results reported here indicate that Argentine hake might become more abundant in the foreseeable future and form summer spawning aggregations off north-eastern Tierra del Fuego. Nevertheless, this interpretation of the results presented here relies on our capacity for accurate 
Fig. 3 Isotopic niches of modern Argentine hake from the Atlantic coast of Tierra del Fuego $(N=20)$ and ancient Argentine hake recovered from Río Chico $1(N=42)$, as revealed by standard ellipse areas corrected for small sample size $\left(\mathrm{SEA}_{\mathrm{C}}\right)$

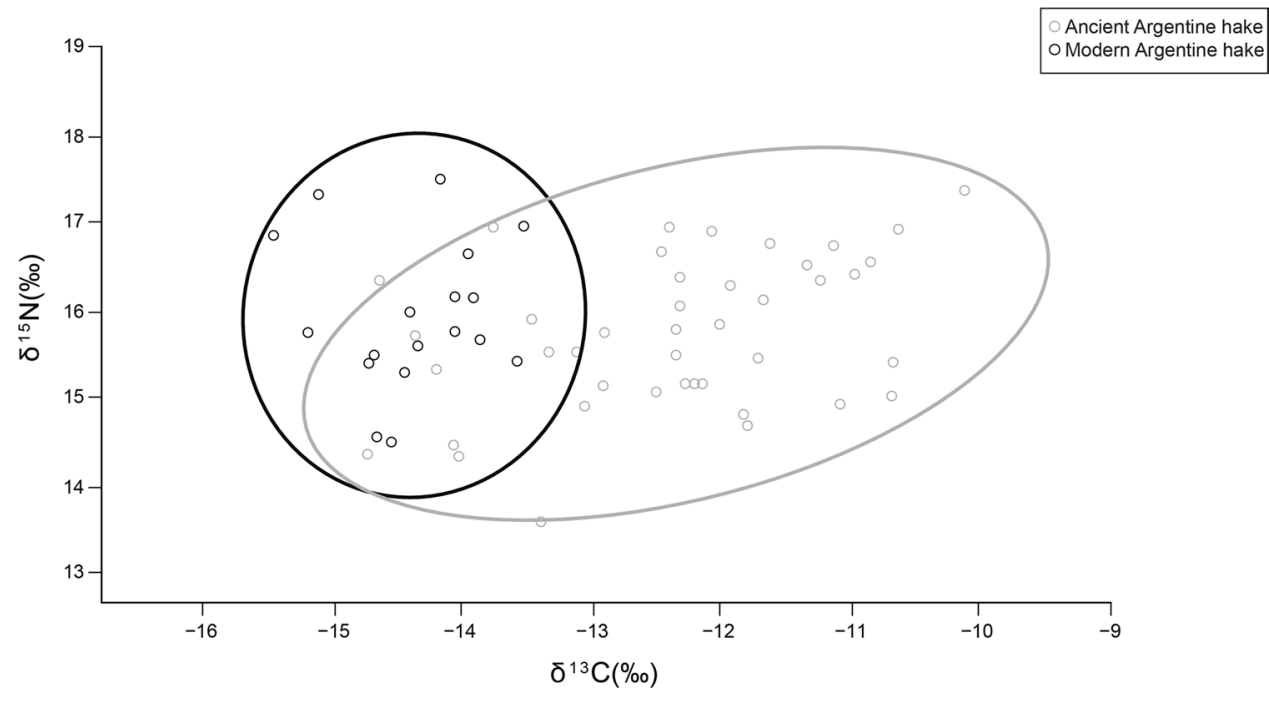

hake species identification, body length assessment and habitat use reconstruction.

Body size can be inferred confidently from fish skeletal elements (Casteel 1976; Smith 1995; Leach and Davidson 2001; Gabriel et al. 2012; Lernau and Ben-Horin 2016) and our results confirm that the dorso-ventral height of the centrum of the first vertebra of hake allow an accurate estimation of body size. On the other hand, the morphology of the first vertebra is of little use to tell apart closely-related species of hake, which is not a surprising result, as often the skeletal elements of species from the same genus are rather similar and have little diagnostic value (Cannon 1988; Yang et al. 2004; Lloris et al. 2005). In this scenario, only molecular methods allow species identification, as far as DNA is preserved in the bone tissue. This is not a problem in the cold environment of Tierra del Fuego, as demonstrated by the high recovery rate for mtDNA reported here and in Evans et al. (2016), but it could be more difficult in warmer regions.

Interpreting changes in stable isotope ratios is more challenging, because potential confounding factors. The most important is the likely historic change in the isotopic baseline, which can be addressed only through adequate correction (Casey and Post 2011). There is growing evidence that the organic matrix of mollusc shells offers a good record of changes in the isotopic baseline (Hill et al. 2006; Casey and Post 2011; Misarti et al. 2017) and is not affected by diagenetic changes (Misarti et al. 2017). Thus, the stable isotope ratios of samples from different periods can be compared directly after an appropriate correction for baseline shifts. Nevertheless, it should be noted that the organic matrix of mollusc shells is a mixture of proteins and chitin, a polysaccharide containing $\mathrm{N}$ (Furuhashi et al. 2009). As a result, the $\mathrm{C}: \mathrm{N}$ ratio of the organic matrix of mollusc shells including equal amounts of protein and chitin is close to 5.5 and hence differs from that of collagen. This does not reduce the suitability of mollusc shells for correcting changes in the isotopic values, although a different benchmark is needed to assess correctly sample preservation and removal of carbonates and lipids.

Here we used the stable isotope ratios of $\mathrm{C}$ and $\mathrm{N}$ in the organic matter of mollusc shells to detect temporal shifts in the isotopic baseline. We averaged the stable isotope ratios in the shells of one species of suspension feeder (mussel) and one species of grazer (limpet), as in previous studies (Saporiti et al. 2014a, b; Zenteno et al. 2015; Bas et al. 2019). The coastal habitat of mussels and limpets is an obvious limitation, because the baseline changes recorded in such coastal species do not necessarily parallel those operating in the offshore habitats used by hake. Unfortunately, no offshore molluscs occur in the middens from Tierra del Fuego, so we assessed changes in the habitat use of hake using two different approaches, one of them dependent and the other independent from any baseline correction (see below).

The $\delta^{15} \mathrm{~N}$ values of contemporary limpets and mussels did not differ, as they have the same trophic position (herbivores). Nevertheless, their $\delta^{15} \mathrm{~N}$ values changed throughout time, except that of limpets from Río Chico 1, which is likely the consequence of small sample size and low statistical power. A declining pattern in the $\delta^{15} \mathrm{~N}$ values of coastal molluscs had been previously reported for the South-Western Atlantic Ocean since the Middle Holocene and interpreted as indicative of a steady decline in marine primary productivity (Saporiti et al. 2014b; Bas et al. 2019). The reason for such decline is unknown, but more intense upwelling has been predicted in eastern boundary currents at high latitudes as a result of global warming (Bakun 1990; Sydeman et al. 2014).

The $\delta^{13} \mathrm{C}$ values of mollusc shells also revealed a baseline change over time but the reasons remain poorly understood. 
Fig. 4 Scatterplot of pelagic and benthic fishes into the $\delta^{13} \mathrm{C}-$ $\delta^{15} \mathrm{~N}$ space. Top panel: ancient samples (6000-5000 cal BP). Bottom panel: modern samples. Error bars show standard deviation
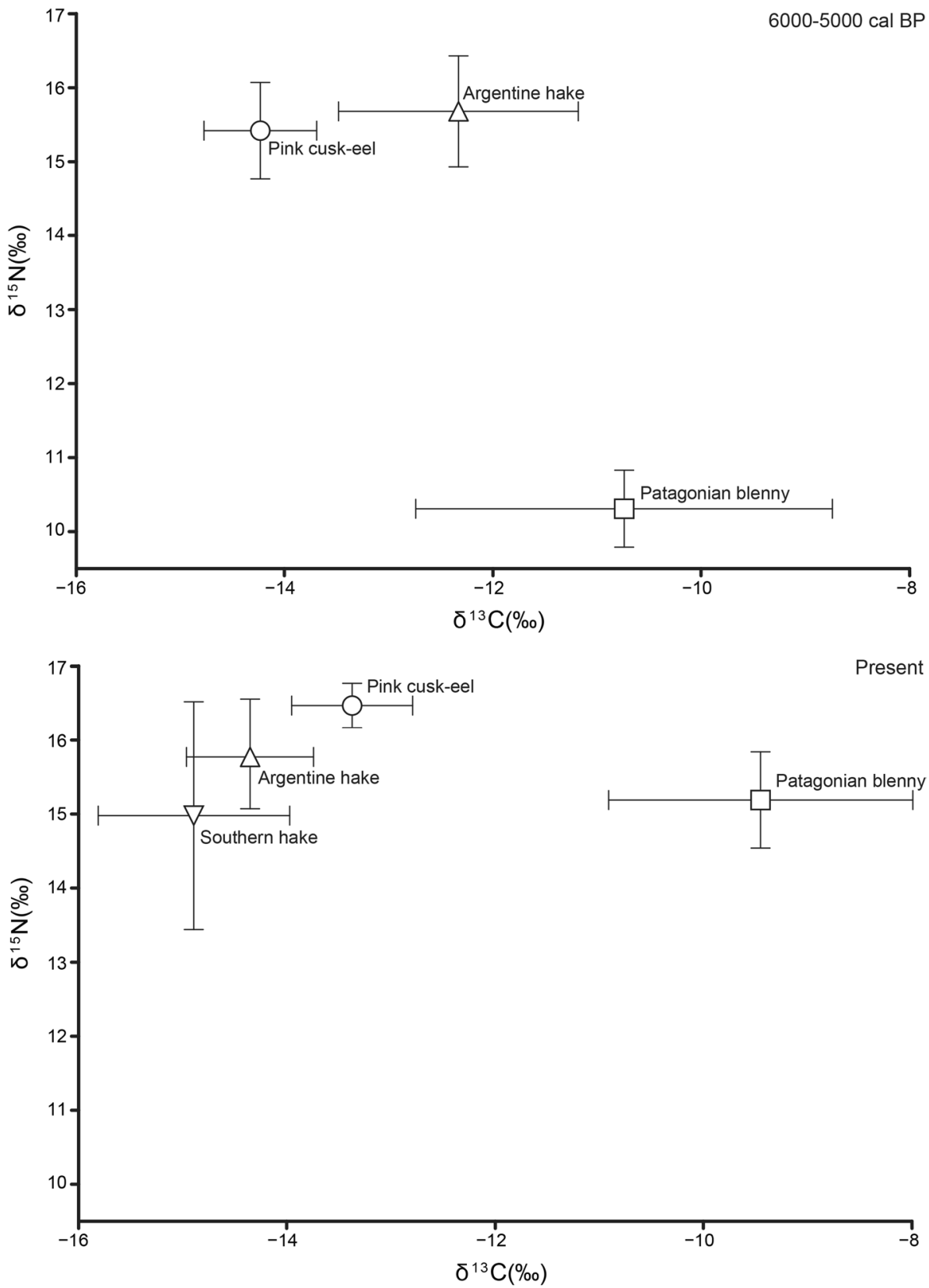

Again, one species from Río Chico 1 did not differ from modern conspecifics, which is likely the consequence of small sample size and low statistical power, but the overall evidence strongly suggests an increase in $\delta^{13} \mathrm{C}$ values. The massive burning of fossil fuels since the Industrial Revolution has resulted in a drop of the $\delta^{13} \mathrm{C}$ values in the atmosphere and the ocean during the past 150 years. Such drop, known as the Suess effect, has been some $-0.5 \%$ in the top $100 \mathrm{~m}$ of the water column off Tierra del Fuego (Eide et al. 2017) and should be recorded in the mollusc shells. However, the $\delta^{13} \mathrm{C}$ values of limpets and mussels are currently higher than in the Middle Holocene, not lower. This means that other processes have operated to alter the isotopic baseline, obscuring the Suess effect. Changes in the $\delta^{13} \mathrm{C}$ values of the primary producers associated to declining marine primary productivity, changes in the relative contribution of different types of primary producers to the organic carbon pool fuelling the food web or both might have operated. Those changes propagated to fish, as the $\delta^{13} \mathrm{C}$ values of all the fish species analysed are currently higher than during the Middle Holocene. Interestingly, changes in the $\delta^{13} \mathrm{C}$ values of benthic consumers (limpets, pink cusk-eel and Patagonian blenny; $4.2 \%$, 3.5\%o and 5.9\%o respectively) were more intense than those in species supported ultimately by phytoplankton (mussels and hake; $1.0 \%$ and $0.6 \%$, respectively). The $\delta^{13} \mathrm{C}$ values of another pelagic forager, 
the Fuegian sprat (Sprattus fuegensis) from the nearby Beagle Channel, have also increased approximately $0.4 \%$ o since 1100 years BP (Bas et al. 2019), thus reinforcing the pattern of a less intense enrichment in ${ }^{13} \mathrm{C}$ in phytoplanktondependent species.

Results reported in this study also revealed significantly lower average $\delta^{13} \mathrm{C}$ values in modern Southern hake than in contemporary Argentine hake, although their ranges overlap. Previous studies also reported large, overlapping ranges of $\delta^{13} \mathrm{C}$ values in the muscle and bone tissue of these species, but formal statistical comparisons were hindered by very small sample sizes (Ciancio et al. 2008; Zangrando et al. 2016). For $\delta^{15} \mathrm{~N}$ and TP, the overall stable isotope evidence (Ciancio et al. 2008; this study) confirms that adult Southern hake have a lower TP than Argentine hake of similar size. Crustaceans dominate the diet of Argentine hake which are less than $30 \mathrm{~cm}$ and fish and cephalopods become more important as hake grow larger, although little change in diet is observed for specimens larger than $50 \mathrm{~cm}$ (Angelescu and Prensky 1987; Belleggia et al. 2014; Botto et al. 2019). This explains why the $\delta^{15} \mathrm{~N}$ and TP values of the adult Argentine hake studied here are uncorrelated with size. The diet of the Southern hake is poorly studied, but a delayed ontogenetic shift compared to Argentine hake might explain why $\delta^{15} \mathrm{~N}$ and TP values are correlated with size even in adult fish. Further research is required on this topic.

The most important finding of this study is the variation of the $\delta^{13} \mathrm{C}$ values of Argentine hake since the Middle Holocene and the resulting shift in the topology of the fish community. Not only ancient and modern Argentine hake differ in average $\delta^{13} \mathrm{C}_{\text {corr }}$ values. Modern Argentine hake also have a smaller standard ellipse area than ancient ones, independent of any correction and thus reveals a much narrower isotopic niche. Furthermore, a large fraction of the isotopic niche of modern Argentine hake is encompassed by that of ancient conspecifics. Differences between average $\delta^{13} \mathrm{C}_{\text {corr }}$ values and the actual overlap between the standard ellipses of ancient and modern Argentine hake are sensitive to the correction factor used to account for baseline shifts, but differences in standard ellipse area are independent of any correction. Thus, there is little doubt that modern Argentine hake have a narrower isotopic niche than ancient ones. A similar reduction has been reported for other species from the South-Western Atlantic Ocean which have been intensely exploited since the arrival of the European societies to South America (Drago et al. 2017; Bas et al. 2019).

Changes in the topology of ancient and modern Argentine hake within the $\delta^{13} \mathrm{C}-\delta^{15} \mathrm{~N}$ biplot in relation to pink cusk-eel and Patagonian blenny are also independent of any baseline correction. Pink cusk-eel and Patagonian blenny differ largely in current habitat use (Pequeño et al. 1995; Cousseau and Perrotta 1998; Villarino 1998; Quiñones and Montes 2001; Licandeo et al.
2006; Riccialdelli et al. 2017) and $\delta^{13} \mathrm{C}$ values (Ciancio et al. 2008; this study) and they also differed largely in their $\delta^{13} \mathrm{C}$ values in the Middle Holocene (this study). The $\delta^{13} \mathrm{C}$ values of ancient Argentine hake were between those of ancient pink cusk-eel and Patagonian blenny from the same water mass, but those of modern Argentine hake are more depleted in ${ }^{13} \mathrm{C}$ than both contemporary pink cuskeel and Patagonian blenny. This is strong evidence that a large fraction of the ancient hake population foraged in shallower areas than currently. Furthermore, the standard deviation of $\delta^{13} \mathrm{C}$ was broader in ancient Argentine hake, thus revealing a higher diversity of foraging strategies, according to the broader isotopic niche above reported.

Conversely, there has been no change in the trophic position of Argentine hake off Tierra del Fuego since the Middle Holocene. Note that differences in the trophic position of ancient and modern Patagonian blenny are likely because of large differences in body size, as this species exhibits a strong ontogenetic dietary shift (Lloris and Rucabado 1991; Cousseau and Perrotta 1998; Martin and Bastida 2008; Bas and Cardona 2018) and the premaxilla of the Patagonian blennies recovered from La Arcillosa 2 were much bigger than those of the modern blennies used for reference.

Changes in SST might have contributed substantially to the habitat shift of Argentine hake reported here. Currently, the population density of Argentine hake is higher in the northern part of Argentine shelf (Boltovskoy 1981; Cousseau and Perrotta 1998) and the southernmost coastal spawning aggregations are reported from areas less than $50 \mathrm{~m}$ deep off Comodoro Rivadavia (46 ${ }^{\circ}$ S) (Bezzi et al. 1995; Díaz de Astarloa et al. 2011; Botto et al. 2019), where the average SST is $11^{\circ} \mathrm{C}$ (Rivas 2010). South of that latitude, Argentine hake are distributed in deeper and colder waters and no coastal spawning aggregation is known (Bezzi et al. 1995; Díaz de Astarloa et al. 2011). Currently, the average SST off north-eastern Tierra del Fuego is $7{ }^{\circ} \mathrm{C}$ (Rivas 2010), but the average SST at that latitude during the Middle Holocene has been reported to be $11-12{ }^{\circ} \mathrm{C}$ (Nielsen et al. 2004; Bentley et al. 2009; Caniupán et al. 2014). Hence, SST values off Río Chico 1 archaeological site during the Middle Holocene likely matched those currently observed off Comodoro Rivadavia. This suggests that Argentine hake would have reached the coast off north-eastern Tierra del Fuego during the summer of the Middle Holocene for spawning, thus becoming vulnerable to hunter-gatherer-fisher people devoid of sailing technology.

In conclusion, increasing SST resulting from global warming could lead to an increase in the abundance of adult Argentine hake onshore Tierra del Fuego and the development of onshore spawning aggregations. Combined with increased primary productivity, this could result into major changes in the fishing industry of the region. 
Acknowledgements Special thanks are due to Matias Pardo from San Arawa fishing company for his help in obtaining modern Southern hake samples. We acknowledge Dr. Begoña López Arias, Universidad Autónoma de Madrid, for her assistance in designing and testing the genetic primers. We are very grateful to Pilar Rubio who helped us with isotopic analyses at Centres Científics $i$ Tecnològics de la Universitat de Barcelona (Barcelona, Spain). Two anonymous reviewers and the handling editor highly improved a previous version of the manuscript with their suggestions. The ancient genetic analysis was supported by the UK Arts and Humanities Research Council (Grant number AH/ N005015/1) and the Leverhulme Trust (through a Philip Leverhulme Prize to CS). This paper was also supported by the following projects: PIP CONICET 0409-13 and PICT 2012-1944 to MS. MB has participated in this work with the support of a doctoral fellowship funded by CONICET for the completion of a $\mathrm{PhD}$ in Biological Sciences at Universidad Nacional de Mar del Plata. All the biological samples included on this paper are obtained, transported and analysed following the legal terms and conditions of the Argentine Government (MTA 19/10/2017).

Author contribution statement $\mathrm{MB}, \mathrm{MA}, \mathrm{IBG}$ and $\mathrm{LC}$ conceived and designed the study. MS and FS conducted the field work. MB, EG, CS and LC conducted laboratory analysis and data analysis. MB and LC wrote the first draft of the manuscript. Other authors provided editorial advice and contributed to revisions.

\section{Compliance with ethical standards}

Conflict of interest The authors declare that they have no conflict of interest.

Informed consent For this type of study formal consent is not required.

\section{References}

Angelescu V, Prenski I (1987) Ecología trófica de la merluza común en el mar Argentino (Merluccidae, Merluccius hubbsi). Parte 2. Dinámica de la alimentación analizada sobre la base de las condiciones ambientales, la estructura y las evaluaciones de los efectivos en su área de distribución. INIDEP 561:205

Bakun A (1990) Global climate change and intensification of coastal ocean upwelling. Science 247:198-201. https://doi.org/10.1126/ science.247.4939.198

Bas M, Cardona L (2018) Effects of skeletal element identity, delipidation and demineralization on the analysis of stable isotope ratios of $\mathrm{C}$ and $\mathrm{N}$ in fish bone. J Fish Biol 92:420-437. https://doi. org/10.1111/jfb. 13521

Bas M, Godino IB, Álvarez M, Vales DG, Crespo EA, Cardona L (2019) Back to the future? Late Holocene marine food web structure in a warm climatic phase as a predictor of trophodynamics in a warmer South-Western Atlantic Ocean. Global Change Biol 25:404-419. https://doi.org/10.1111/gcb.14523

Belleggia M, Figueroa D, Irusta G, Bremec C (2014) Spatio-temporal and ontogenetic changes in the diet of the Argentine hake Merluccius hubbsi. J Mar Biol Assoc 94:1701-1710. https://doi. org/10.1017/S0025315414000629

Bentley MJ, Hodgson DA, Smith JA, Cofaigh CO, Domack EW, Larter RD, Roberts SJ, Brachfeld S, Lebenter A, Hjort C, Hillenbrand C-D, Evans J (2009) Mechanisms of Holocene paleoenvironmental change in the Antarctic Peninsula region. Holocene 19:51-69. https://doi.org/10.1177/0959683608096603
Bertolotti MI, Verazay GA, Errazti E, Pagani AN, Buono JJ (2001) Flota pesquera Argentina: Evolución durante el período 19601998, con una actualización al 2000. In: Bertolotti MI, Verazay GA, Akselman R (eds) El mar Argentino y sus recursos pesqueros. INIDEP, Mar del Plata, pp 9-53

Bezzi SI, Verazay GA, Dato CV (1995) Biology and fisheries of Argentine hakes (M. hubbsi and M. australis). In: Alheit J, Pitcher TJ (eds) Hake. Springer, Dordrecht, pp 239-267

Bolle LJ, Rijnsdorp AD, van Neer W, Millner RS, van Leeuwen PI, Ervynck A, Ayers R, Ongenae E (2004) Growth changes in plaice, cod, haddock and saithe in the North Sea: a comparison of (post-) medieval and present-day growth rates based on otolith measurements. J Sea Res 51:313-328. https://doi.org/10.1016/j.seare s.2004.01.001

Boltovskoy E (1981) Masas de agua en el Atlántico Sudoccidental. In: Boltovskoy E (ed) Atlas del Zooplancton del Atlántico Sudoccidental y Métodos de Trabajo con el Zooplancton Marino. INIDEP, Mar del Plata, pp 227-237

Botto F, Gaitán E, Iribarne OO, Acha EM (2019) Trophic niche changes during settlement in the Argentine hake Merluccius hubbsi reveal the importance of pelagic food post metamorphosis. Mar Ecol Prog Ser 619:125-136. https://doi.org/10.3354/meps12947

Braje TJ, Rick TC, Szpak P, Newsome SD, McCain JM, Elliott Smith EA, Glassow M, Hamilton SL (2017) Historical ecology and the conservation of large, hermaphroditic fishes in Pacific Coast kelp forest ecosystems. Sci Adv 3:e1601759. https://doi.org/10.1126/ sciadv.1601759

Bujalesky GG (2007) Coastal geomorphology and evolution of Tierra del Fuego (Southern Argentina). Geol Acta 5:337-362

Campo D, Machado-Schiaffino G, Perez J, Garcia-Vazquez E (2007) Phylogeny of the genus Merluccius based on mitochondrial and nuclear genes. Gene 406:171-179. https://doi.org/10.1016/j. gene.2007.09.008

Caniupán M, Lamy F, Lange CB, Kaiser J, Kilian R, Arz HW, León T, Mollenhauer G, Sandoval S, De Pol-Holz R, Pantoja S, Wellner J, Tiedemann R (2014) Holocene sea-surface temperature variability in the Chilean fjord region. Quat Res 82:342-353. https:// doi.org/10.1016/j.yqres.2014.07.009

Cannon A (1988) Radiographic age determination of Pacific salmon: species and seasonal inferences. J Field Archaeol 15:103-108. https://doi.org/10.1179/009346988791974583

Casey MM, Post DM (2011) The problem of isotopic baseline: reconstructing the diet and trophic position of fossil animals. Earth Sci Rev 106:131-148. https://doi.org/10.1016/j.earscirev.2011.02.001

Casteel RW (1976) Fish remains in archaeology and paleo-environmental studies. Academic Press, New York

Caut S, Angulo E, Courchamp F (2009) Variation in discrimination factors $\left(\Delta^{15} \mathrm{~N}\right.$ and $\left.\Delta^{13} \mathrm{C}\right)$ : the effect of diet isotopic values and applications for diet reconstruction. J Appl Ecol 46:443-453. https ://doi.org/10.1111/j.1365-2664.2009.01620.x

Ciancio JE, Pascual MA, Botto F, Frere E, Iribarne O (2008) Trophic relationships of exotic anadromous salmonids in Southern Patagonian Shelf as inferred from stable isotopes. Limnol Oceanogr 53:788-798

Cousseau MB, Perrotta R (1998) Peces marinos de Argentina. Biología, distribución, pesca. INIDEP, Mar del Plata

DeNiro MJ (1985) Postmortem preservation and alteration of in vivo bone collagen isotope ratios in relation to palaeodietary reconstruction. Nature 317:806-809

Díaz de Astarloa JM, Bezzi SI, González Castro M, Mabragaña E, Hernández D, Delpiani SM, Figueroa DE, Cousseau MB, Deli Antoni MY, Tringali L (2011) Morphological, morphometric, meristic and osteological evidence for two species of hake (Actinopterygii: Gadiformes: Merluccius) in Argentinean waters. J Fish Biol 78:1336-1358. https://doi.org/10.111 1/j.1095-8649.2011.02937.x 
Drago M, Cardona L, Franco-Trecu V, Crespo EA, Vales D, Borella F, Zenteno L, Gonzáles EM, Inchausti P (2017) Isotopic niche partitioning between two apex predators over time. J Anim Ecol 86:766-780. https://doi.org/10.1111/1365-2656.12666

Eide M, Olsen A, Ninnemann US, Eldevik T (2017) A global estimate of the full oceanic ${ }^{13} \mathrm{C}$ Suess effect since the preindustrial. Global Biogeochem Cycles 31:492-514. https://doi.org/10.1002/2016G B005472

Enghoff IB, MacKenzie BR, Nielsen EE (2007) The Danish fish fauna during the warm Atlantic period (ca. 7000-3900 bc): forerunner of future changes? Fish Res 87:167-180. https://doi.org/10.1016/j. fishres.2007.03.004

Evans S, Godino IB, Álvarez M, Rowsell K, Collier P, Goodall RNP, Mulville J, Lacrouts A, Collins MJ, Speller C (2016) Using combined biomolecular methods to explore whale exploitation and social aggregation in hunter-gatherer-fisher society in Tierra del Fuego. J Archaeol Sci: Rep 6:757-767. https://doi.org/10.1016/j. jasrep.2015.10.025

Folch J, Lees M, Stanley GHS (1957) A simple method for the isolation and purification of total lipides from animal tissues. J Biol Chem 226:497-509

Friedlander AM, Nowlis J, Koike H (2014) Improving fisheries assessments using historical data. In: Kittinger JN, McClenachan L, Gedan KB, Blight LK (eds) Marine historical ecology in conservation: applying the past to manage for the future. University of California Press, Berkeley, pp 91-118

Furuhashi T, Schwarzinger C, Miksik I, Smrz M, Beran A (2009) Molluscan shell evolution with review of shell calcification hypothesis. Com Biochem Physiol Part B 154:351-371. https://doi. org/10.1016/j.cbpb.2009.07.011

Gabriel S, Prista N, Costa MJ (2012) Estimating meagre (Argyrosomus regius) size from otoliths and vertebrae. J Archaeol Sci 39:28592865. https://doi.org/10.1016/j.jas.2012.04.046

Guiry EJ, Szpak P, Richards MP (2016) Effects of lipid extraction and ultrafiltration on stable carbon and nitrogen isotopic compositions of fish bone collagen. Rapid Commun Mass Spectrom 30:1591-1600. https://doi.org/10.1002/rcm.7590

Hall TA (2001) BioEdit: a user-friendly biological sequence alignment editor and analysis, version 5.09. North Carolina University, Chapel Hill

Hiddink JG, Ter Hofstede R (2008) Climate induced increases in species richness of marine fishes. Global Change Biol 14:453-460. https://doi.org/10.1111/j.1365-2486.2007.01518.x

Hill JM, McQuaid CD, Kaehler S (2006) Biogeographic and nearshore-offshore trends in isotope ratios of intertidal mussel beds and their food sources around the coast of southern Africa. Mar Ecol Prog Ser 318:63-73. https://doi.org/10.3354/meps318063

Hoegh-Guldberg O, Bruno JF (2010) The impact of climate change on the world's marine ecosystems. Science 328:1523-1528. https:// doi.org/10.1126/science. 1189930

Jackson JB, Kirby MX, Berger WH, Bjorndal KA, Botsford LW, Bourque BJ, Bradbury RH, Cooke R, Erlandson J, Estes JA, Hughes TP, Kidwell S, Lange CB, Leniham HS, Pandolfi JM, Peterson CH, Steneck RS, Tegner MJ, Warner RR (2001) Historical overfishing and the recent collapse of coastal ecosystems. Science 293:629-637. https://doi.org/10.1126/science.1059199

Jackson AL, Inger R, Parnell AC, Bearhop S (2011) Comparing isotopic niche widths among and within communities: SIBER-Stable Isotope Bayesian Ellipses in R. J Anim Ecol 80:595-602. https:// doi.org/10.1111/j.1365-2656.2011.01806.x

Layman CA, Arrington DA, Montaña CG, Post DM (2007) Can stable isotope ratios provide for community-wide measures of trophic structure? Ecology 88:42-48. https://doi.org/10.1890/00129658(2007)88[42:CSIRPF]2.0.CO;2

Leach F, Davidson J (2001) The use of size-frequency diagrams to characterize prehistoric fish catches and to assess human impact on inshore fisheries. Int J Osteoarchaeol 11:150-162. https://doi. org/10.1002/oa.553

Lernau O, Ben-Horin M (2016) Estimations of sizes of fish from subfossil bones with a logarithmic regression model. Environ Archaeol 21:133-136. https://doi.org/10.1080/14614 103.2016.1157676

Licandeo RR, Barrientos CA, González MT (2006) Age, growth rates, sex change and feeding habits of notothenoid fish Eleginops maclovinus from the central-southern Chilean coast. Environ Biol Fishes 77:51-61. https://doi.org/10.1007/s10641-006-9054-z

Lloris D, Rucabado J (1991) Ictiofauna del Canal Beagle (Tierra del Fuego): Aspectos ecológicos y análisis biogeográfico. Publicación Especial 8. IEO, Madrid

Lloris D, Matallanas J, Oliver P (2005) Hakes of the World (Family Merlucciidae): an annotated and illustrated catalogue of hake species known to date (No. 2). FAO, Rome

Lotze HK, Erlandson JM, Hardt MJ, Norris RD, Roy K, Smith TD, Whitcraft CR (2011) Uncovering the ocean's past. In: Jackson JBC, Alexander KE, Sala E (eds) Shifting baselines. Island Press, Washington, pp 137-161

Martin JP, Bastida R (2008) Contribución de las comunidades bentónicas en la dieta del róbalo (Eleginops maclovinus) en la ría Deseado (Santa Cruz, Argentina). Lat Am J Aquat Res 36:1-13. https://doi. org/10.4067/S0718-560X2008000100001

Misarti N, Gier E, Finney B, Barnes K, McCarthy M (2017) Compound-specific amino acid $\delta^{15} \mathrm{~N}$ values in archaeological shell: assessing diagenetic integrity and potential for isotopic baseline reconstruction. Rapid Commun Mass Spectrom 31:1881-1891. https://doi.org/10.1002/rcm.7963

Morales A, Rosenlund K (1979) Fish bone measurements. Steenstrupia. Zoological Museum, Copenhagen

Newsome SD, Koch PL, Etnier MA, Aurioles-Gamboa D (2006) Using carbon and nitrogen isotope values to investigate maternal strategies in Northeast Pacific otariids. Mar Mammal Sci 22:556-572. https://doi.org/10.1111/j.1748-7692.2006.00043.x

Nielsen SH, Koç N, Crosta X (2004) Holocene climate in the Atlantic sector of the Southern Ocean: controlled by insolation or oceanic circulation? Geology 32:317-320. https://doi.org/10.1130/G2033 4.1

Pequeño G, Lamilla J, Lloris D, Rucabado J (1995) Comparación entre las ictiofaunas intermareales de los extremos austral y boreal de los canales patagónicos. Rev Biol Mar 30:155-177

Perry AL, Low PJ, Ellis JR, Reynolds JD (2005) Climate change and distribution shifts in marine fishes. Science 308:1912-1915. https ://doi.org/10.1126/science.1111322

Posada D, Crandall KA (1998) Modeltest: testing the model of DNA substitution. Bioinformatics 14:817-818. https://doi.org/10.1093/ bioinformatics/14.9.817

Quiñones RA, Montes RM (2001) Relationship between freshwater input to the coastal zone and the historical landings of the benthic/ demersal fish Eleginops maclovinus in central-south Chile. Fish Oceanogr 10:311-328

Rambaut A (2007) FigTree, a graphical viewer of phylogenetic trees. https://tree.bio.ed.ac.uk/software/figtree. Accessed 3 Dec 2018

Riccialdelli L, Newsome SD, Fogel ML, Fernández DA (2017) Trophic interactions and food web structure of a subantarctic marine food web in the Beagle Channel: Bahía Lapataia, Argentina. Polar Biol 40:807-821. https://doi.org/10.1007/s00300-016-2007-x

Rivas AL (2010) Spatial and temporal variability of satellite-derived sea surface temperature in the southwestern Atlantic Ocean. Cont Shelf Res 30:752-760. https://doi.org/10.1016/j.csr.2010.01.009

Ronquist F, Huelsenbeck JP (2003) MrBayes 3: Bayesian phylogenetic inference under mixed models. Bioinformatics 19:1572-1574. https://doi.org/10.1093/bioinformatics/btg180

Salemme M, Bujalesky G, Santiago F (2007) La Arcillosa 2: la ocupación humana durante el Holoceno medio en el Rió Chico, 
Tierra del Fuego, Argentina. In: Morello F, Martinic M, Prieto A, Bahamonde G (eds) Arqueologiá de Fuego-Patagonia: levantando Piedras, Desenterrando huesos... y Develando Arcanos. Ediciones CEQUA, Punta Arenas, pp 723-736

Salemme MC, Santiago FC, Oria J (2014) La Arcillosa 2: Registro Zooarqueológico de la Ocupación Humana durante el Holoceno Medio, Tierra del Fuego, Argentina. Rev Chil Antrop 29:19-25. https://doi.org/10.5354/0719-1472.2015.36201

Santiago FC (2013) La ocupación humana del norte de Tierra del Fuego durante el Holoceno medio y tardío: su vinculación con el paisaje. Editora Cultural Tierra del Fuego, Ushuaia

Santiago F, Gordillo S, Salemme M (2014) Moluscos en contextos arqueológicos de la costa Atlántica de Tierra del Fuego: Consumo prehistórico e implicancias de su distribución actual. Rev Chil Antrop 29:40-48. https://doi.org/10.5354/0719-1472.2015.36204

Saporiti F, Bala LO, Gómez Otero J, Crespo EA, Piana EL, Aguilar A, Cardona L (2014b) Paleoindian pinniped exploitation in South America was driven by oceanic productivity. Quat Int 352:85-91. https://doi.org/10.1016/j.quaint.2014.05.015

Saporiti F, Bearhop S, Silva L, Vales DG, Zenteno L, Crespo EA, Aguilar A, Cardona L (2014a) Longer and less overlapping food webs in anthropogenically disturbed marine ecosystems: confirmations from the past. PLoS ONE 9:e103132. https://doi.org/10.1371/ journal.pone. 0103132

Scartascini FL, Volpedo AV (2013) White croaker (Micropogonias furnieri) paleodistribution in the Southwestern Atlantic Ocean. An archaeological perspective. J Archaeol Sci 40:1059-1066. https:// doi.org/10.1016/j.jas.2012.08.032

Shevenell AE, Ingalls AE, Domack EW, Kelly C (2011) Holocene Southern Ocean surface temperature variability west of the Antarctic Peninsula. Nature 470:250-254

Simpson SD, Jennings S, Johnson MP, Blanchard JL, Schön PJ, Sims DW, Genner MJ (2011) Continental shelf-wide response of a fish assemblage to rapid warming of the sea. Curr Biol 21:1565-1570. https://doi.org/10.1016/j.cub.2011.08.016

Skrzypek G (2013) Normalization procedures and reference material selection in stable HCNOS isotope analyses: an overview. Anal Bioanal Chem 405:2815-2823

Smith P (1995) A regression equation to determine the total length of hake (Merluccius merluccius) from selected measurements of the bones. Int J Osteoarchaeol 5:93-95. https://doi.org/10.1002/ oa. 1390050110

Speller CF, Hauser L, Lepofsky D, Moore J, Rodrigues AT, Moss ML, McKechnie I, Yang DY (2012) High potential for using DNA from ancient herring bones to inform modern fisheries management and conservation. PLoS ONE 7:e51122. https://doi.org/10.1371/ journal.pone.0051122

Swetnam TW, Allen CD, Betancourt JL (1999) Applied historical ecology: using the past to manage for the future. Ecol Appl 9:11891206. https://doi.org/10.1890/1051-0761(1999)009[1189:AHEUT P]2.0.CO;2
Sydeman WJ, García-Reyes M, Schoeman DS, Rykaczewski RR, Thompson SA, Black BA, Bograd SJ (2014) Climate change and wind intensification in coastal upwelling ecosystems. Science 345:77-80. https://doi.org/10.1126/science.1251635

Szpak P, Buckley M, Darwent CM, Richards MP (2018) Long-term ecological changes in marine mammals driven by recent warming in northwestern Alaska. Global Change Biol 24:490-503. https:// doi.org/10.1111/gcb.13880

Thompson JD, Higgins DG, Gibson TJ (1994) CLUSTAL W: improving the sensitivity of progressive multiple sequence alignment through sequence weighting, position-specific gap penalties and weight matrix choice. Nucleic Acids Res 22:4673-4680. https:// doi.org/10.1093/nar/22.22.4673

Torres J (2009) La pesca entre los cazadores recolectores terrestres de la Isla Grande de Tierra del Fuego, desde la prehistoria a tiempos etnográficos. Magallania 37:109-138. https://doi.org/10.4067/ S0718-22442009000200007

Vales DG, Cardona L, Zangrando AF, Borella F, Saporiti F, Goodall RNP, de Oliveira LR, Crespo EA (2017) Holocene changes in the trophic ecology of an apex marine predator in the South Atlantic Ocean. Oecologia 183:555-570. https://doi.org/10.1007/s0044 2-016-3781-4

Villarino MF (1998) Distribución estacional y estructura de tallas del abadejo (Genypterus blacodes) en el Mar Argentino. INIDEP, Mar del Plata, pp 1-25

Yang DY, Eng B, Waye JS, Dudar JC, Saunders SR (1998) Improved DNA extraction from ancient bones using silica-based spin columns. Am J Phys Anthropol 105:539-543. https://doi. org/10.1002/(SICI)1096-8644(199804)105:4\%3C539:AIDAJPA10\%3E3.0.CO;2-1

Yang DY, Cannon A, Saunders SR (2004) DNA species identification of archaeological salmon bone from the Pacific Northwest Coast of North America. J Archaeol Sci 31:619-631. https://doi. org/10.1016/j.jas.2003.10.008

Yang DY, Liu L, Chen X, Speller CF (2008) Wild or domesticated: DNA analysis of ancient water buffalo remains from north China. J Archaeol Sci 35:2778-2785. https://doi.org/10.1016/j. jas.2008.05.010

Zangrando AF, Riccialdelli L, Kochi S, Nye JW, Tessone A (2016) Stable isotope evidence supports pelagic fishing by hunter-gatherers in southern South America during the Late Holocene. J Archaeol Sci Rep 8:486-491. https://doi.org/10.1016/j.jasrep.2016.05.015

Zenteno L, Borella F, Gómez Otero J, Piana E, Belardi JB, Borrero LA, Saporiti F, Cardona L, Crespo EA (2015) Shifting niches of marine predators due to human exploitation: the diet of the South American sea lion (Otaria flavescens) since the late Holocene as a case study. Paleobiology 41:387-401. https://doi.org/10.1017/ pab.2015.9 